\title{
A Rare Case of Combined Vesico-Vaginal and Vesico-Cutaneous Fistulae Treated by One-Stage Surgical Repair
}

\author{
Sunday Jenner Lengmang1,3, Edwin Oseni-Momodu², Paul Ushie ${ }^{2,3}$, \\ George Anyuku Azubuike Chima $^{3}$ \\ ${ }^{1}$ Evangel Vesico Vaginal Fistula Centre, Bingham University Teaching Hospital, Jos, Nigeria \\ ${ }^{2}$ Surgery Department, Bingham University, Jos Campus, Jos, Nigeria \\ ${ }^{3}$ Family Medicine Department, Bingham University, Jos campus, Jos, Nigeria \\ Email: sunday.lengmang@gmail.com
}

How to cite this paper: Lengmang, S.J., Oseni-Momodu, E., Ushie, P. and Chima, G.A.A. (2017) A Rare Case of Combined Vesico-Vaginal and Vesico-Cutaneous Fistulae Treated by One-Stage Surgical Repair. Open Journal of Obstetrics and Gynecology, 7, 702-706.

https://doi.org/10.4236/ojog.2017.77070

Received: May 25, 2017

Accepted: July 9, 2017

Published: July 12, 2017

Copyright $\odot 2017$ by authors and Scientific Research Publishing Inc. This work is licensed under the Creative Commons Attribution International License (CC BY 4.0).

http://creativecommons.org/licenses/by/4.0/

\begin{abstract}
Combined vesico-vaginal and vesico-cutaneous fistulae are exceptionally rare. We present a young woman who had combined vesico-vaginal fistula and vesico-cutaneous fistula following prolonged obstructed labour and caesarean section. The patient presented at three months of illness with total urine incontinence from the vagina and lower abdominal skin. One-stage surgical repair of both fistulae was done. The patient had a successful closure of the fistulae, regained full urinary continence, and remained continent at six months follow-up. We opine that one-stage repair of combined vesico-vaginal and vesico-cutaneous fistulae is feasible and preferred. Providers of pelvic surgery in low resource countries should be supervised and retrained accordingly, in order to prevent iatrogenic vesico-cutaneous fistula.
\end{abstract}

\section{Keywords}

Vesico-Vaginal, Vesico-Cutaneous, Fistula, Iatrogenic

\section{Introduction}

Urinary fistulae result from a breach in the integrity of the renal system. Urine then by-passes its pathway to surrounding structures which are devoid of sphincteric control. The result is incontinence of urine which has devastating physical, social and psychological consequences [1].

Obstetric fistula persists in low resource countries [1] [2], decades after it was eradicated in developed countries [1]. Whereas vesico-vaginal fistula (VVF) is the most common type of urinary fistula [1], vesico-cutaneous fistula (VCF) is 
rare [3], a combination of the two is exceptionally rare.

Globally, the prevalence of female genital fistula was estimated to be 3,000,000, while the incidence was estimated to be 130,000 in Africa [1]. The most common cause of VVF is obstructed labour [1]. Other causes are pelvic trauma, female genital mutilation, cancer of the cervix, lymphogranuloma venereum and iatrogenic causes like complications of pelvic surgery. On the other hand the most common cause of VCF is iatrogenic [3], while other causes include: pelvic trauma, large bladder calculi and irradiation [4].

Since VVF relegates its victims to a life of misery [4], a combination of VVF and VCF could be more devastating. Consequently, rapid surgical intervention is required to limit suffering among women with urinary fistula while its prevention should be a public health priority.

Our objective is to report a very rare case of combined vesico-vaginal fistula and vesico-cutaneous fistula, and the successful one-stage surgical treatment.

\section{Case}

A 24 year old G1P1 presented with three-month history of urinary incontinence following caesarean delivery for prolonged obstructed labour. She leaked urine from the vagina and the lower anterior abdominal skin. She had no history of pelvic swelling, haematuria or pyouria.

On examination she was well hydrated but her clothes were wet with urine from her waist downwards. She had normal vital signs and her chest was clinically clear with normal vesicular breath sounds. There was a Pfannenstiel scar on her lower abdomen, part of which was wet. A defect was seen towards the middle of the Pfannenstiel scar from which urine was seen to be oozing when the lower abdomen was palpated. The uterus was normal sized and there was no pelvic mass or abdominal hernia.

Pelvic speculum examination revealed an obvious defect between the bladder and vagina through which urine leaked. When weak methylene blue solution was instilled into the bladder through a urethral catheter, the anterior vaginal wall and lower abdomen were directly observed (Direct dye test), the dye was seen to leak through the bladder defect to the vagina and the Pfannenstiel scar defect. A provisional diagnosis of combined vesico-vaginal fistula and vesicocutaneous fistula was made.

Her packed cell volume was 35\% and urea and creatinine were within normal limits. Pelvic ultrasound could not be done as it was not possible for urine to be retained within the bladder. Cystoscopy was not done as the bladder could be seen through the VVF defect.

The patient consented for an examination under anaesthesia and one-stage surgical repair of both fistulae under spinal anaesthesia. In the theatre, routine cleaning and draping were done under spinal anaesthesia. Examination under anaesthesia was done. The fistula defects were estimated to be $5 \times 4 \mathrm{~cm}$ on the vagina (VVF) and $4 \times 3 \mathrm{~cm}$ on the Pfannenstiel scar (VCF). The bladder was inspected from the vaginal defect, which revealed an empty bladder with both ureters actively spilling urine. A uterine sound passed from the VCF through the 
bladder, exited at the VVF (Figure 1). The diagnosis of combined vesico-vaginal fistula and vesico-cutaneous fistula was confirmed.

The VVF was incised via an inverted " $\mathrm{T}$ " shaped incision and the bladder was sharply dissected from the anterior vaginal wall. The bladder margin of the fistula was excised and repaired with a tension free absorbable suture in one layer. The anterior vaginal wall was also repaired in one layer using absorbable suture. The margin of the VCF was then incised, trimmed and the bladder dissected off the anterior abdominal skin. Both structures were repaired with tension free absorbable sutures in separate layers. Post closure direct dye test with $200 \mathrm{mls}$ of dye showed no dye leak from the vagina and anterior abdominal wall. The bladder was drained with an indwelling size 16 Foley's catheter for fourteen days. After removal of the catheter, both fistulae had closed and the patient had regained continence and remained continent at six months follow up.

\section{Discussion}

Obstetric fistula persists in low income countries decades after it was eradicated from the developed world [4]. VVF, the most common cause of obstetric fistula frequently follows prolonged obstructed labour. VCF, on the other hand are mostly iatrogenic [3] [5].

Women with VVF have significant distress from urinary incontinence [1] [4]. A combination of VVF and VCF could worsen the distress. Some urinary fistulae could be successfully treated with urethral catheterization alone [6]. In this case, since the fistulae were large and have persisted for three months, it was germane to first repair the fistulae surgically, before urethral catheterization.

Abdominal ultrasonography was deferred because both fistulae were large, making it impossible to retain urine in the bladder. This could obscure ultrasonographic findings. Furthermore, the urea and creatinine resuls were normal and examination under anaesthesia revealed ureters that were actively spilling urine. The direct dye test and the examination under anaesthesia were therefore sufficient for diagnosis in our low-resource setup. In the management of vesi co-cutaneous fistula, others have used abdominal ultrasonography and CT

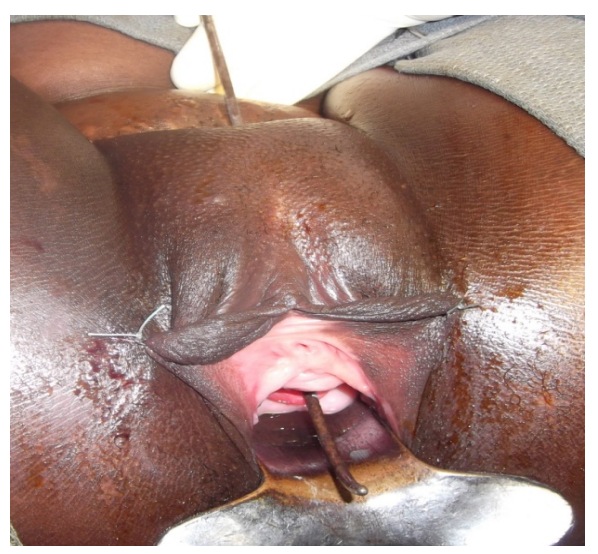

Figure 1. Uterine sound demonstrating vesico-cutaneous and vesico-vaginal fistulae. 
cystograms [5] where the fistula was tiny and very difficult to appreciate by direct dye test alone.

Although we could not find a combined VVF and VCF in published literature, one-stage repair of other types of combined fistulae have been reported with good outcome [7], and that has been our experience and practice. One-stage, rather than multi-stage repair of the fistulae was preferred by our patient and our team in view of its advantages: it appears to hasten relief of physical, emotional and psychological burden of the illness by shortening the duration of illness; and promote early restoration of health and social reintegration [7]. Furthermore, a single exposure of the patient to hospital admission, anaesthesia and surgery reduces risk.

Surgical closure of VCF with interposition of omental flap has been reported [5]. However, tension free closure was done in this case without omental flap because the surrounding tissue looked good and the margin of the fistula was trimmed to ensure removal of avascular tissue that might interfere with healing.

One-stage surgical repair of combined fistulae could be challenging. Depending on the degree of tissue loss, bringing together the available bladder tissue for a tension free closure may be difficult. In this case, wide dissection enabled a tension free closure with a successful outcome. The rest of the management and follow up was uneventful and our patient regained full continence, thus confirming effectiveness of one-stage surgical repair of combined VVF and VCF.

Prevention of obstetric fistula is possible [1], and should be the focus rather than cure. Community or institutional interventions like health education, family planning, antenatal care with identification and proper management of women at risk of obstetric fistula, active management of labour using parthograph [1] are known interventions addressing obstetric fistula prevention. The concurrence of VVF and VCF in this patient calls for a broad approach for tackling the multiple aetiology of obstetric fistula in low resource countries, especially iatrogenic VCF. Concerns about the adequacy of training and supervision of providers of pelvic procedures like caesarean section in low resource countries have been raised [8]. Healthcare workers providing surgical services in low resource countries need to be supervised and retrained accordingly, in order to prevent iatrogenic VCF.

\section{Conclusion}

Combined vesico-vaginal and vesico-cutaneous fistula is exceptionally rare. One-stage surgical repair of combined VVF and VCF is feasible and preferred. Healthcare workers providing surgical services in low resource countries need to be supervised in order to prevent iatrogenic VCF.

\section{Consent}

A written informed consent was obtained from the patient for the publication of this article. 


\section{Conflict of Interest Statement}

We declare no conflict of interest.

\section{References}

[1] Wall L.L. (2006) Obstetric Vesicovaginal Fistula as an International Public-Health Problem. The Lancet, 368, 1201-1209.

https://doi.org/10.1016/S0140-6736(06)69476-2

[2] Kirschner C.V., Yost K.J., Du, H., Karshima, J.A., Arrowsmith, S.D. and Wall, L.L. (2010) Obstetric Fistula: The ECWA Evangel VVF Center Surgical Experience from Jos, Nigeria. International Urogynecology Journal, 21, 1525-1533. https://doi.org/10.1007/s00192-010-1231-0

[3] Lodulf, I., Apel, H., Jorch, R.E. and Beier, J.P. (2014) Treatment of a Chronic Vesico Abdominal Wall Defect after Resection of a Soft Tissue Sarcoma Using Bidedcled Latissimus Dorsi and Serratus Anterior Free Flap. International Journal of Urology, 21, 1178-1180. https://doi.org/10.1111/iju.12545

[4] Wall L.L. (1998) Dead Mothers and Injured Wives: The Social Context of Maternal Morbidity and Mortality among the Hausa of Northern Nigeria. Studies in Family Planning, 29, 341-359. https://doi.org/10.2307/172248

[5] Basatac, C. and Cicek, M.C. (2015) Vesicocutaneous Fistula Treatment Using Omental Flap Interposition. Journal of Surgical Case Reports, 2015, 4.

https://doi.org/10.1093/jscr/rjv004

[6] Toufique, H. and Merani, A.J. (2011) Vesicocutaneous Fistula. Journal of Pakistan Medical Association, 61, 918-919.

[7] Ojengbede, O.A., Morhason-Bello, I.O. and Shittu, O. (2007) One Stage Repair for Combined Fistulas: Myth or Reality? International Journal of Gynecology and $\mathrm{Ob}$ stetrics, 99, S90-S93. https://doi.org/10.1016/j.ijgo.2007.06.022

[8] Shephard, S.N. and Lengmang, S.J. (2015) The Path of Least Resistance: A Case of Cervical Stenosis and Ureterocutaneous Fistula. Case Reports in Women's Health, 8, 4-5. https://doi.org/10.1016/j.crwh.2015.08.00

\section{Submit or recommend next manuscript to SCIRP and we will provide best service for you:}

Accepting pre-submission inquiries through Email, Facebook, LinkedIn, Twitter, etc. A wide selection of journals (inclusive of 9 subjects, more than 200 journals) Providing 24-hour high-quality service User-friendly online submission system Fair and swift peer-review system Efficient typesetting and proofreading procedure Display of the result of downloads and visits, as well as the number of cited articles Maximum dissemination of your research work

Submit your manuscript at: http://papersubmission.scirp.org/

Or contact ojog@scirp.org 